\title{
BRUCELLOSIS IN MARINE MAMMALS, WITH SPECIAL EMPHASIS ON THE REPUBLIC OF CROATIA
}

\author{
Željko Cvetnić1, Sanja Duvnjak ${ }^{1}$, Martina Đuras², Tomislav Gomerčić2, \\ Maja Zdelar-Tuk ${ }^{1}$, Irena Reil ${ }^{1}$, Boris Habrun ${ }^{1}$, Silvio Špičić ${ }^{1}$ \\ ${ }^{1}$ Croatian Veterinary Institute, Zagreb, Croatia; \\ ${ }^{2}$ Faculty of Veterinary Medicine, University of Zagreb, Zagreb, Croatia
}

\section{Summary}

After almost two decades of research and evidence of brucellosis in marine mammals, it has become widely known that this disease is prevalent in marine mammals on a global scale. Positive animals have been found in the northern Atlantic, Mediterranean Sea and in the Arctic, including the Barents Sea. Infected or exposed animals have been detected along the Atlantic and Pacific coasts of North America, off the coasts of Peru, Australia, New Zealand, Hawaii, the Solomon Islands, and in the Antarctic Ocean. Brucellosis most commonly occurs in the harbour porpoise (Phocoena phocoena), followed by the striped dolphin (Stenella coeruleoalba), Atlantic white-sided dolphin (Lagenorhynchus acutus), bottlenose dolphin (Tursiops truncatus), shortbeaked common dolphin (Delphinus delphis) and minke whale (Balaenoptera acutorostrata). A positive serological reaction has been confirmed in 35 species of whales and 14 species of seals, two subspecies of sea otters, one species of freshwater otter and the polar bear. To date, brucellosis has been found in marine mammals in the Mediterranean Sea in Italy and Spain. The first research on brucellosis in dolphins in the Republic of Croatia began in 2015. Brucella sp. was isolated from the lymph node of a bottlenose dolphin found dead in the Poreč region. This was the first evidence of brucellosis in dolphins in the Adriatic Sea. The isolated sample was identified as Brucella ceti strain ST27, making this the first record of this strain in Europe, which may present a significant threat to human health.

Keywords: marine mammals; dolphin; brucellosis; Brucella ceti ST27; Croatia.

\section{INTRODUCTION}

Brucellosis has been identified and proven in whales, dolphins, seals, sea lions, walruses and otters. This disease appears to be widely distributed in marine mammals, and the clinical signs include placentitis and miscarriage, neonatal mortality, meningoencephalitis, and skin abscesses. Potential hosts for Brucellasp.in aquat- 
ic systems may consist of some 130 species of marine and freshwater mammals that live and feed in the seas, rivers and lakes. This includes 86 different species of whales of the order Cetacea, suborder Mysticetia (baleen whales) and suborder Odontocetia (toothed whales) that also comprises the dolphins, 36 species belonging to the ordo Carnivora, suborder Pinnipedia (seals), including the families Otariidae (eared seals), Odobenidae (walruses), and Phocidae (seals). Other mammals that may be infected include the sea otter (Enhydra lutris), marine otter(Lutra felina), polar bear (Ursus maritimus), manatee (Trichechus sp.), and dugong (Dugong dugong). Natural infection has also been recorded in humans, primarily those professionally exposed to marine mammals [1].

\section{ETIOLOGY}

Brucella (B.) sp. was first isolated in 1994 from the carcasses of harbour seal (Phoca vitulia), harbour porpoise (Phocoena phocoena) and short-beaked common dolphin (Delphinus delphis) beached along the coast of Scotland, and from the aborted young of a bottlenose dolphin in captivity in California [2,3]. Initially, all strains were called B. maris [4]. Later studies indicated there were in fact two species of Brucella cetacean. Isolates from whales were initially called Brucella cetacean [5]. In 2007, they were renamed Brucella ceti, as the natural hosts were confirmed to be the whales (cetaceans). Isolates from seals differed from B. ceti and were called B. pinnipedialis, with seals (Phocidae) as the natural hosts [6-9].

\section{TRANSMISSION OF BRUCELLOSIS IN MARINE MAMMALS}

The route of transmission of brucellosis among marine mammals has not yet been fully elucidated. It is believed that infections in whales may be transmitted sexually, or in contact with aborted off spring and placental tissue. Vertical transfer from mother to offspring is known [10-12]. In seals, the route of transmission is insufficiently known, though their communal lifestyle and constant direct contact between animals spurs the spread of infection. Lung nematodes (Pseudalius inflexus) are considered as possible vector for brucellosis in the marine environment. Brucella has been found in the reproductive organs and intestinal lumen of lung nematodes isolated from dolphins and seals. In their lifecycle, parasites migrate through the respiratory system of sea lions, enter into the digestive system and move into the environment through excrement. The opaleye fish (Girella nigricans) and other intermediaries, such as coprophagous fish, eat the contaminated faeces. These fish are later consumed by marine mammals, and the larvae are released in the digestive tract of the mammals, when thay migrate into the lungs and the cycle continues [13]. 


\section{DISTRIBUTION OF BRUCELLOSIS IN MARINE MAMMALS}

After almost two decades of research and evidence of brucellosis in marine mammals, it has become well known that this disease is globally distributed in marine mammals. Bacteriologically or serologically positive animals have been found in the Northern Atlantic, Mediterranean Sea and in the Arctic, including the Barents Sea. Infected or exposed animals have been found along the Atlantic and Pacific coasts of North America, the coast of Peru, Australia, New Zealand and Hawaii, on the Solomon Islands, and in the Antarctic [14-17]. The most recent research has also proven the presence of brucellosis in the bottlenose dolphin in Croatia, in the northern Adriatic Sea [18].

Specific comparative analyses have shown that certain species of whales and dolphin are more susceptible to Brucella infection than others. Among the toothed whales, brucellosis most often affects the harbour porpoise (Phocoena phocoena), striped dolphin (Stenella coeruleoalba), Atlantic white-sided dolphin (Lagenorhynchus acutus), bottlenose dolphin (Tursiops truncatus) and short-beaked common dolphin (Delphinus delphis) and minke whale (Balaenoptera acutostrata). The average incidence of brucellosis in marine mammals varies among species. Research has been conducted in different geographic areas on different sample sizes. To date, about $4 \%$ of the investigated marine mammals have been found to be serologically positive in the Atlantic, Pacific and Arctic Oceans. In less comprehensive studies, seroprevalence ranges from 0 to $80 \%$. Positive serological reactions have been confirmed in 35 whale species and 14 seal species, two sea otter subspecies, onefreshwater otter species, and in the polar bear [1,19].

\section{BRUCELLA CETI}

$B$. ceti has been isolated from both suborders of whales: Mysticeti, the baleen whales, and Odontoceti, the toothed whales. The first suborder includes four families of baleen whales, which feed by filtering plankton (rorquals) and skim feeding (right and pygmy whales), or by filtering the silt off the seabed (grey whales). The suborder of toothed whales includes a group of nine families, including the sperm whales and pygmy sperm whales, beaked whales, dolphins and porpoises, as well as the Indian and South American river dolphins. B. ceti has been determined (by isolation or PCR) in only four families: Balaenopteridae (rorquals), Phocoenidae (porpoises), Delphinidae (dolphins, killer whales, pilat whales and relatives) and Monodontidae (belugas and narwhals). Brucella has been proven in many species, such as the harbour porpoise (Phocoena phocoena), bottlenose dolphin (Tursiops truncatus), striped dolphin (Stenella coeruleoalba), white-beaked dolphin (Lagenorhynchus albiros- 
tris), killer whale (Orcinus orca) and others. Antibodies have been proven in seven families and 35 different species, suggesting the conclusion that Brucella infections in marine mammals in the whale families is very common $[3,15,20,21]$.

The majority of isolates have been derived from whales beached on the shores of the Atlantic Ocean in North America and Europe, and on the southwestern and eastern coasts of the Pacific Ocean. Isolates in Europe are primarily from the Northern Atlantic and North Sea off Scotland, Spain, England and Wales. In the western Atlantic, Brucella strains have been isolated in mammals off the coasts of New England and the entire eastern seaboard of the United States, and in the Gulf of Mexico. Brucella strains have also been isolated in the eastern and southwestern Pacific [22-24]. Brucella infections in marine mammals are globally distributed [25]. Infections with the species $B$. ceti are specific to the nervous system, and have been described in two cetacean species: striped dolphin (Stenella coeruleoalba) in Europe and off the coast of Costa Rica, and in the Atlantic white-sided dolphin off the coast of Great Britain. Though all the strains isolated from whales belong to the species $B$. ceti, three different groups of strains are known based on their preferred host, certain bacteriological properties, and specific genetic traits: the strains isolated from short-beaked common dolphin (ST23), from the harbour porpoise (ST26) and from humans (ST27). It is believed that the strains isolated from the dolphins and porpoises are variable in experiments on terrestrial animals, and are not infectious for humans. However, brucellosis has proven to be a highly chronic disease in certain common dolphins and harbour porpoises, with severe clinical signs and pathological signs relating to abortions, male infertility, neurobrucellosis, cardiopathology, bone lesions and skin, beachings and ultimately in death [22].

The presence of antibodies has been proven in 58 serum samples originating from toothed whales caught in Peru in the period from 1993 to 1995 and from 24 whales beached along the Spanish coast in the period from 1997 to 1999. Positive serological reactions were confirmed in 21 (77.8\%) of 27 samples originating from the dusky dolphin (Lagenorhynchus obsurus), in 3 (50\%) of 6 samples of long-beaked common dolphin (Delphinus capensis), in 8 (35\%) of 23 samples of bottlenose dolphin (Tursiops truncatus), in 5 (25\%) of 20 Burmeister's porpoise (Phocoena spinipinnis) and in 2 (33\%) of 6 samples of striped dolphin (Stenella coeruleoalba) [24]. Off the Pacific coast of Costa Rica, B. ceti was isolated from 6 striped dolphins (Stenella coeruleoalba) [11]. In the period from 2008 to 2011, a total of 112 harbour porpoises (Phocoena phocoena) were found dead off the Dutch coast, and these animals were tested for brucellosis. Of these animals, $5(4.5 \%)$ were positive for Brucella sp. Molecular analysis showed that the strain was B. ceti ST 23 [43]. B. ceti has also been isolated from harbour porpoises (Phocoena phocoena) washed up on the beaches of Belgium [26]. 


\section{BRUCELLA PINNIPEDIALIS}

B. pinnipedialis has been isolated from seals of the families Phocidae (seals) and Otariidae (sea lions). Six species of seals have been found to harbour this disease: hooded seal (Cystophora cristata), ringed seal (Phoca hispida), harp seal (Phoca groenlandica), grey seal (Halichoerus grypus), harbour seal (Phoca vitulina). This species of Brucella has also been isolated from the California sea lion (Zalophus californianus). Antibodies have been found in 17 different marine mammal species from the order Carnivora, subordo Pinnipedia (families Otariidae, Odobenidae, Phocidae) and subordo Fissipedia (families Mustelidaeand Ursidae), steller sea lion, Australian sea lion, Antarctic fur seal, South American fur seal, walrus, harbour seal, Pacific harbour seal, harp seal, grey seal, Hawaiian monk sea lion, hooded seal, leopard seal, Weddell's seal, Alaskan sea otter, California sea otter, European otter, and the polar bear. Isolates have been found from animals in the northern Atlantic (Northern Ireland, New England, Canada), the North Sea (Scotland, Germany), and the Pacific Ocean (California, USA). B. pinnipedialis has been isolated from hooded seals or from beached animals or seemingly healthy individuals captured in their natural environment [1,27,28]. Following the isolation of Brucella from porpoises and whales in Scotland and in Northern England, serological testing was also conducted on other marine mammals that could be exposed to Brucella infections along the coasts of England and Wales. In the period from 1989 to 1995, 153 serum samples were collected from marine mammals. Positive serological reactions were recorded in $6(10 \%)$ of 62 grey seals (Halichoerus grypus), in 1 (8\%) of 12 harbour seals (Phoca vitulina), in 11 (31\%) of 35 samples of harbour porpoises (Phocoena phocoena) and in 9 (20\%) of 44 samples of short-beaked common dolphins (Delphinus delphis) [29]. Antibodies for B. pinipedialis were most often found in common seals (Phoca vitulina) in 3 (14\%) of 21 samples and in 4 of 53 (8\%) harp seals (Phoca groenlandica). A particularly high incidence of serologically positive animals (35\%) was confirmed in the hooded seal (Cystophora cristata) in the northern part of the Atlantic Ocean and Barents Sea. In $49 \%$ of tested samples of common seal from Scotland, brucellosis antibodies were confirmed, as in $21 \%$ of samples from North America and $75 \%$ of tested samples of sea lions from Australia [23]. Brucellosis antibodies were detected in 35\% of samples of hooded seals (Cystophora cristata), in 2\% of harp seals (Phoca groenlandica) and in $10 \%$ of ringed seals (Phoca hispida). Research has shown that brucellosis is widely distributed among marine mammals in the northern Atlantic [30]. Antibodies were confirmed in 16 (5.4\%) of 297 tested serum samples in polar bear (Ursus maritimus) from the Svalbard islands and in the Barents Sea. Antibodies were found in the same area in ringed seal (Phoca hispida) and harp seal (Phoca groenlandica), and these 
seal species represent an important dietary source for bears, and as such could be an important source of infection [31]. Brucellosis was confirmed in 11 (38\%) of 29 seemingly healthy hooded seals (Cystophora cristata)captured in their natural habitat in the northern Atlantic Sea and Greenland [28]. Brucellosis antibodies were confirmed in polar bear (Ursus maritimus) in Alaska, in the range of $6.8 \%$ to $18.5 \%$ of processed samples [32].

\section{DISTRIBUTION OF BRUCELLOSIS IN MARINE MAMMALS IN THE MEDITERRANEAN SEA}

In the Mediterranean Sea, brucellosis has been confirmed in marine mammals in Italy, Spain and Croatia (Figure 1). Brucella sp. was first isolated in the Mediterranean Sea from the brain, lungs and lymph nodes of the striped dolphin(Stenella coeruleoalba) in Italy in 2012 in the Tyrrhenian Sea (off the coast of Tuscany) (Figure 1, number 1). This isolate was classified as Brucella ceti type 1, and multi-locus sequencing (MLST) categorised it as belonging to the strain B. ceti ST 26 [33].Other described cases of brucellosis were in two striped dolphins (Stenella coeruleoalba) washed up in southern Italy, on the Ionian coast of the Mediterranean Sea. Brucellosis was isolated from dolphins in the area of Galipolli Lido Pizzo in March 2012 and again in November 2012 from dolphins in the area Porto Cesareo Bacino. Both isolates were molecularly confirmed to belong to the strain B. ceti ST 26 [19]. (Figure 1, number 2). Brucellosis was confirmed in two striped dolphins (Stenella coeruleoalba) found on the shores of Catalonia in Spain (Salou and Badalona areas) and in the bottlenose dolphin (Tursiops truncatus) (Qunit) in Spain. Two striped dolphins were found alive, one with signs of neurobrucellosis, including reduced mobility, side swimming and a lack of coordination, while the second showed no clinical symptoms. The corpse of a bottlenose dolphin was soon found washed ashore. The organs tested from all three dolphins contained B. ceti, and MLST testing categorised the samples as belonging to the strain B. ceti ST 26 [34], (Figure 1, number 3).

\section{BRUCELLOSIS IN MARINE MAMMALS IN THE REPUBLIC OF CROATIA}

The bottlenose dolphin (Tursiops truncatus) is widely distributed in the Mediterranean Sea. It is the only permanent resident in the Croatian waters of the Adriatic Sea. This species is associated (resident) to the area it lives in, creating communities of varying size. Other cetaceans found occasionally in the Adriatic Sea are the striped dolphin (Stenella coeruleoalba), Risso's dolphin (Grampus griseus), and Cuvier's beaked whale (Ziphius cavirostris). Considering the small area and closed nature of 
Rad 530. Medical Sciences, 44(2017) : 9-24

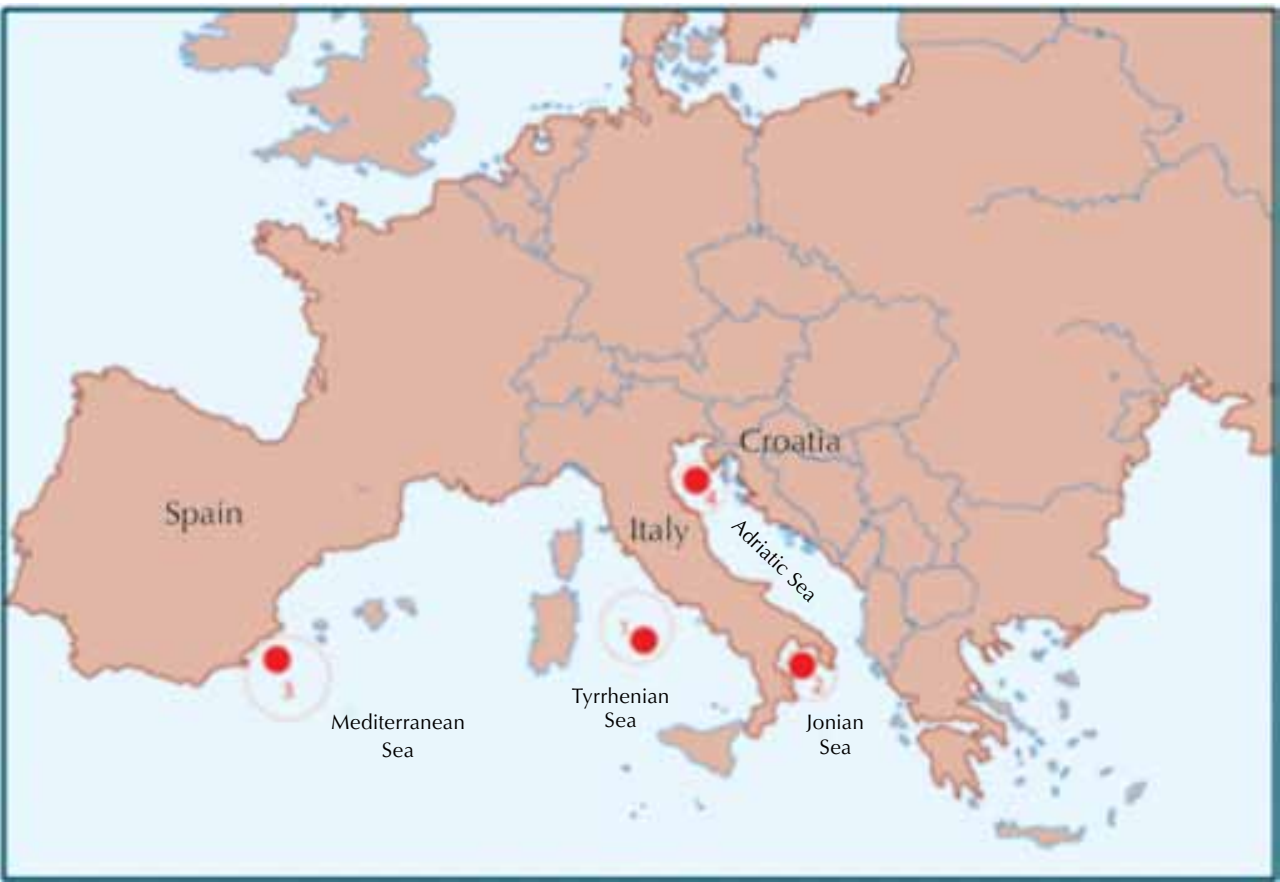

Figure 1. Distribution of brucellosis in dolphins in the Mediterranean Sea. In Italy (numbers 1 and 2), Spain (3) and Croatia (4).

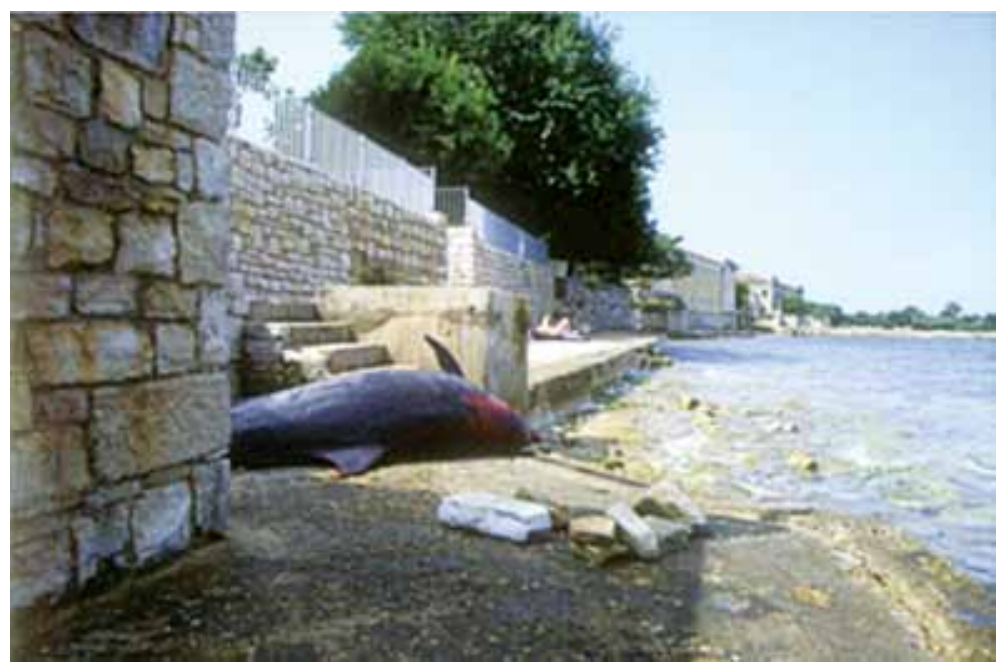

Figure 2. A dead bottlenose dolphin (Tursiopsus truncatus) beached on the shores of the Adriatic Sea. 
the Adriatic Sea, coupled with strong human population pressures, particularly from the summer tourism season, dolphins in the Adriatic face numerous threats. In Croatia, $50 \%$ of all dolphin deaths are from anthropogenic causes, including capture or entanglement in fishing nets, intentional deaths by fishermen, or killings for other reasons. Some animals also die of natural causes (Figures 2,3 and 4).

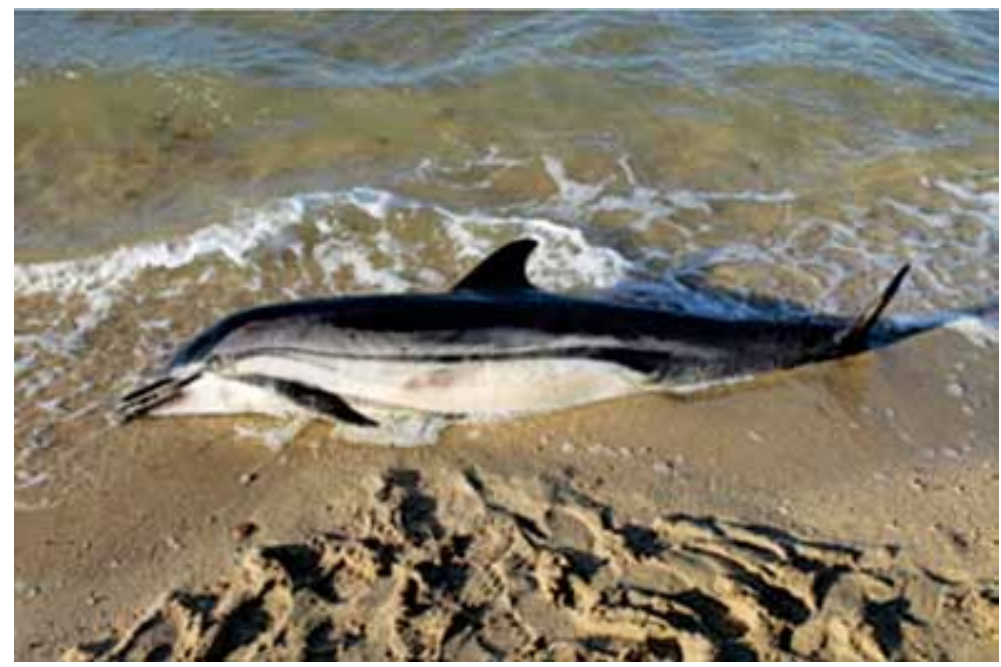

Figure 3. A dead striped dolphin (Stenella coeruleoalba) beached on the shore of the Adriatic Sea.
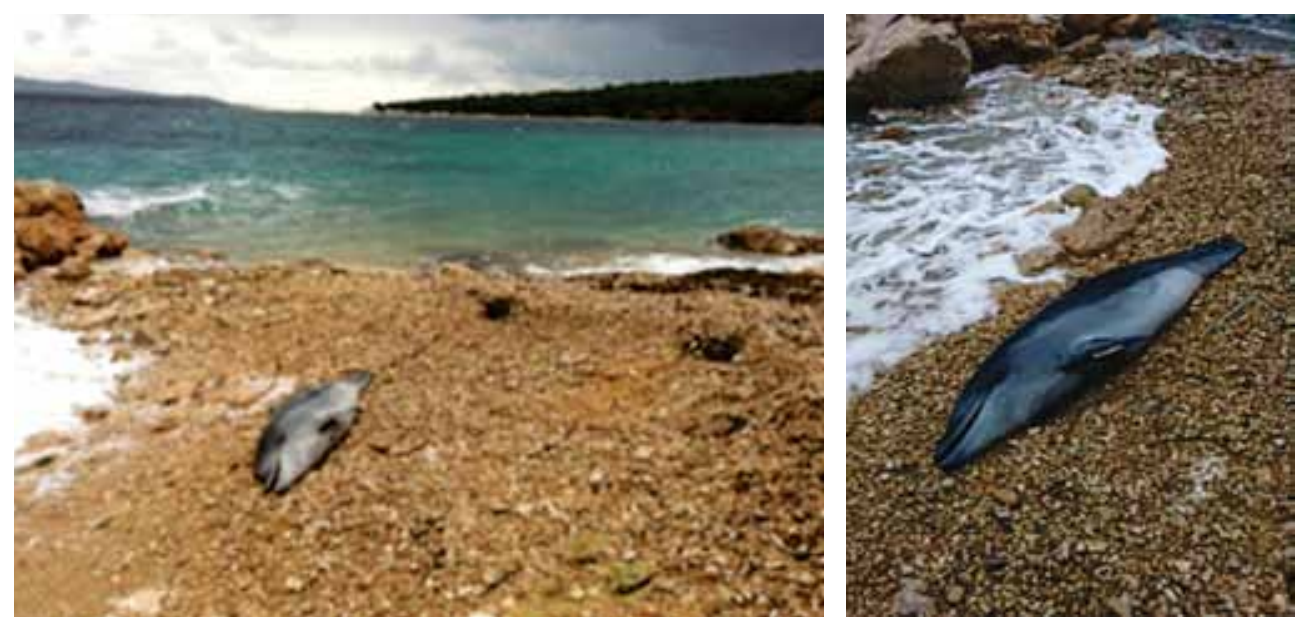

Figure 4. Corpse of a dead bottlenose dolphin. It is evident that the dead dolphins have no fluke, likely they were cut off after entanglement in a fishing net. 


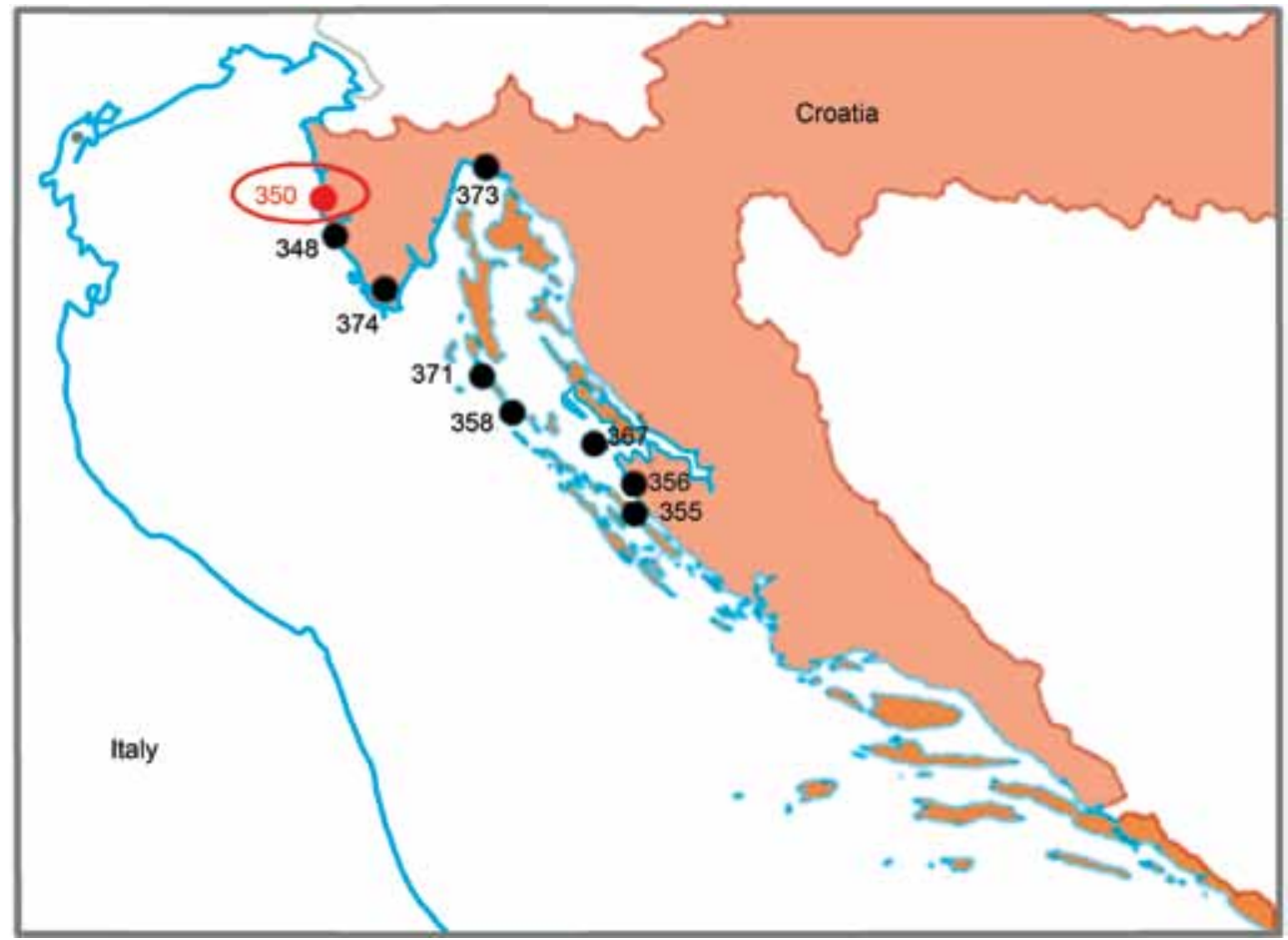

Figure 5. An overview of sites in the Croatian part of the Adriatic Sea where bottlenose dolphin corpses were found and tested for brucellosis.
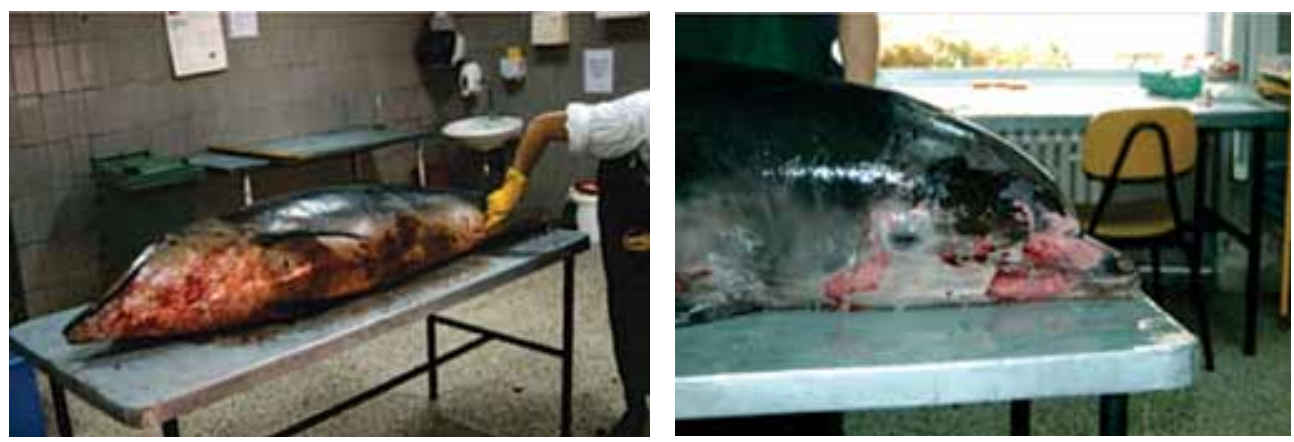

Figure 6. Bottlenose dolphin (Tursiops truncatus) no. 350 prior to posmortal examination the Department of Anatomy, Histology and Embriology, Faculty of Veterinary Medicine, University of Zagreb. 
The first research on brucellosis in dolphins in the Republic of Croatia began in summer 2015. During 2015 and 2016, a total of 9 dolphins found dead at the following locations were tested: Rovinj (348), Poreč (350), Ošljak (355), Molat (356), Lošinj (358), Vir (367), Lošinj (371), Rijeka (373), Pula (374), (Figure 5). Brucella sp. was isolated from the lymph nodes of bottlenose dolphin no. 350, found near Poreč (Figure 6).

Isolate (no. 350) was isolated on the fifth day after inoculation on Farrell agar at $37^{\circ} \mathrm{C}$. The available molecular methods confirmed it belonged to the genus Brucella. Conventional PCR methods confirmed the presence of the gene BCSP-31, and 100\% homology with known Brucella species, including species isolated from marine mammals based on the $16 \mathrm{~S}$ rDNA sequences of [35,36]. Identification of the species

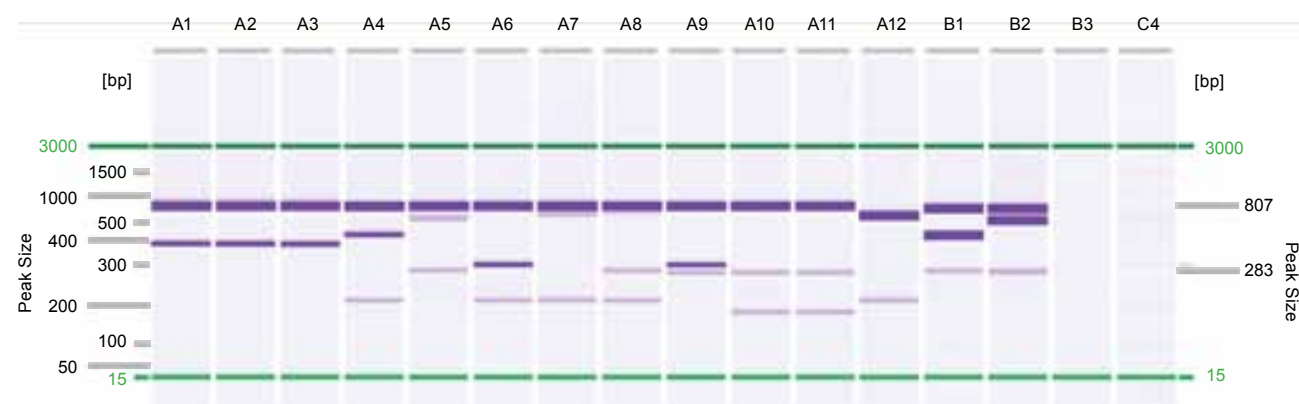

Figure 7. Multiplex - suis (Suis - ladder) (A1 - strain 350/1, A2 - strain 350/2, A3 - strain 350/3, A4 - B.suis referential strain (r.s.) bv.1, A5 - B.suis r.s. bv.2, A6 - B.suis r.s. bv.3, A7 - B.suis r.s. bv.4, A8 - B.suis r.s. bv.5, A9 - r. s. B. abortus S99, A10 - r.s. B. melitensis 16M, A11 - r.s. B. ovis REO 198, A12 - r.s. B. canis RM 666, B1 - B. pinnipedialis soj, B2 - B.ceti soj, B3 - negative control, B4 - size marker).

within the genus was conducted using multiplex PCR known as the Bruce-ladder method [37]. Other multiplex PCR methods such as Suis-ladder also used in order to identify the correct Brucella species [38], (Figure 7).

With the aim of differentiating the species B.ceti and B. pinnipedialis, additional primers were used $[34,38,39]$. Correct species could still not be determined with certainty. Therefore, further genotyping analyses of the strain were necessary for the identification of the number of tandem repeats on 16 gene loci, MLVA method [40,41], and sequence analysis of nine gene locio MLST method [42]. These methods gave more detailed phylogenetic information and important epidemiological data. Only MLST method gave the final determination that this strain was Brucella ceti ST27. This is the first record of brucellosis in a dolphin in the Adriatic Sea, and the first record of the strain ST27 in Europe, which also presents a human health risk [18], (Figure 8). 


\section{DIAGNOSTICS,} TREATMENT AND SUPERVISION OF BRUCELOSIS IN MARINE MAMMALS

There are no specific clinical symptoms that would indicate brucellosis in marine mammals. The disease may be suspected in cases of miscarriage or pathological findings of orchitis, epidydimitis, subcutaneous skin abscesses, meningitis or meningoencephalitis, or in the case of certain systematic diseases. Brucellosis has also been isolated from the organs of healthy animals. In order to better understand the pathogenesis, epizootiology and epidemiology of brucellosis, sources of infections in marine

Figure 8. Minimum Spanning Tree (MST) depiction of results of the MLST method on the isolated strain 350 in comparison with strains available in the Brucella2012 database. Strains are marked as belonging to the species $B$. ceti or B. pinnipedialis and origin, in which the colours listed in the legend represent countries.
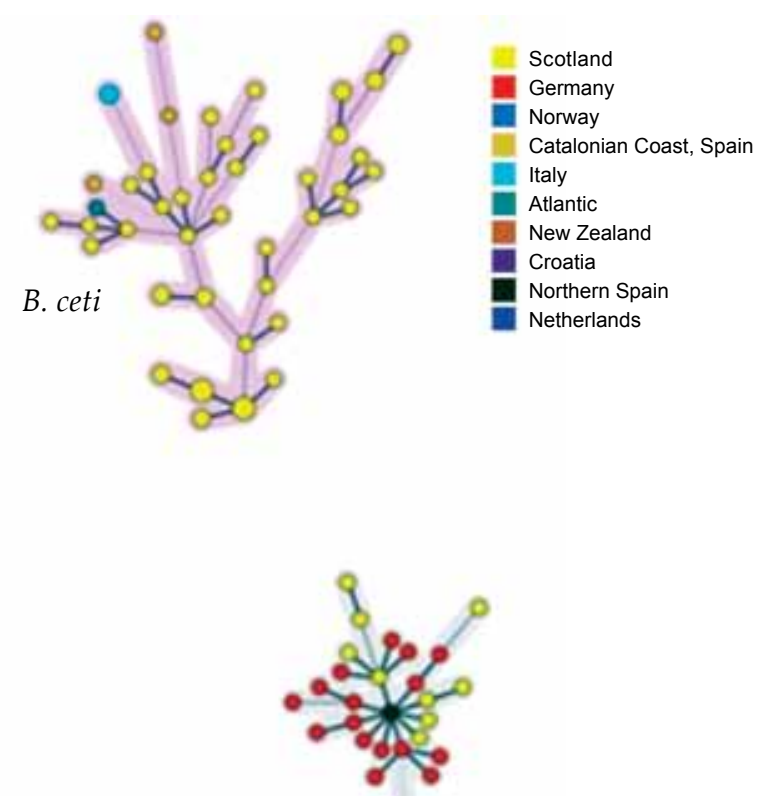

B. pinnipedialis

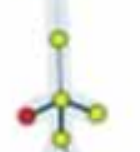

$\mathrm{CRO} \quad$ New Zealand

B. ceti ST 27

B. ceti 
mammals in the oceans and seas around the world, it is necessary to perform objective diagnostics and, wherever possible, to isolate and identify Brucella strains. Attempts to treat dolphins in captivity using antibiotics have proven to be ineffective. Due to the long-standing intracellular survival of Brucella in the body and the risk of the spread of infection to other animals and humans, it is considered essential and justified to properly dispose of positive animals, particularly those with clinical complications. There is no systematic supervision system for brucellosis in marine mammals, either for living animals or for those found dead or beached. Also human infections and spread of the disease are possible. The meat and organs for further consumption are rarely tested. Most often, marine mammals are captured and processed without any additional precautionary measures. Both species, B. ceti and B. pinnipedialis, have all the properties of infectivity, and can infect humans or other animal species [43].

\section{References}

[1] Hernandez-Mora G, Palacios-Alfaro JD, Gonzales-Barrientos R. Wildlife reservoir of brucellosis: Brucella in aquatic environments. Rev Sci Tech Off Int Epiz. 2013;32:89-103.

[2] Ewalt DR, Payeur JB, Martin BM, Cummins DR, Miller WG. Characteristics of Brucella species from a bottlenose dolphin (Tursiops truncatus). J Vet Diagn Invest.1994;6:448-52.

[3] Ross HM, Jahans KL, MacMillan AP, Reid RJ, Thompson PM, Foster G. Brucella species infection in North Sea seal and cetacean populations. Vet Rec. 1996; 138: 647-8.

[4] Jahans KL, Forster G, Brougton ES. The characterisation of Brucella strains isolated from marine mammals. Vet Microbiol. 1997;57:373-82.

[5] Cloeckaert A, Verger JM, Grayon M, Paquet JY, Garin-Bastuji B, Forster G, Godfroid J. Classification of Brucella spp. isolated from marine mammals by DNA polymorphism at the omp2 locus. Microbes Infect. 2001;3:729-38.

[6] Corbel MJ, Morgan WJB. Proposal for minimal standards for descriptions of new species and biotypes of the genus Brucella. Int. J. Syst. Bacteriol. 1975;25:83-9.

[7] Corbel MJ, Gill KPW, Thomas EL. Methods for the identification of Brucella. Central Veterinary Laboratory, New Haw, Weybridge, 1983;1-63.

[8] Foster G, Macmillan AP, Godfroid JF, Howie H, Ross M, Cloeckaert A, Reid RJ, Brew S, PattersonI A. A review of Brucella spp. Infection of sea mammals with particular emphasis on isolates from Scotland. Vet Microbiol. 2007;90:563-80.

[9] Ostrman B, Moriyon I. International committee on systematic of prokaryotes. Subcommittee on the taxonomy of Brucella. Int J Syst Evol Microbiol. 2006;56:1173-5.

[10] Gonzales-Barrientos R, Morales JA, Hernandez-Mora G, Barquero-Calvo E, GuzmanVerri C, Chavez- Olarte E, Moreno E. Pathology of striped dolphins (Stenella coeruleoalba) infected with Brucella ceti. J Comp Pathol. 2010;142:347 
[11] Hernandez-Mora G, Gonzales-Barrientos R, Morales JA, Chavez-Olarte E, Guzman-Verri C, Barquero-Calvo E, De MigueI MJ, Marin CM, Blasco JM, Moreno E. Neurobrucellosis in stranded dolphins, Costa Rica. Emer Infect Dis. 2008;14:1430-3.

[12] Maquart M, Le Fleche P, Foster G, Tryland M, Ramisse F, Djonne B, Al Dahouk S, Jacques I, Neubauer H, Walravens K, Godfroid J, Cloeckaert A, Vergnaut G. MLVA-16 typing of 295 marine mammal Brucella isolates from different animal and geographic origins identifies 7 major groups within Brucella ceti and Brucella pinnipedialis. BMC Microbiol. 2009;9:145-55.

[13] Dawson CE, Perrett LL, Stubberfield EJ, Stack JA, Farrelly SS, Cooley WA, Davison NJ, Quinney S. Isolation and characterization of Brucella from the lungworms of a harbour porpoise (Phocoena phocoena). J Wildl Dis. 2008;44:237-46.

[14] Hernandez-Mora G, Maire CA, Gonzales-Barrientos R, Morales JA, Chavez-Olarte E, Guzman-Verri C, Staggs L, Thompson R, Moreno E. Serological diagnosis of Brucella infections in odontocetes. Clin Vaccine Immunol. 2009;16:906-15.

[15] Munoz PM, Garcia-Castillo G, Lopez-Garcia P, Gonzales-Cuelli J, De Miguel MJ, Marin CM, Barberan M, BlascoJ M. Isolation of Brucella species from alive-stranded striped dolphin (Stenella coeruleoalba) in Spain. Vet Rec. 2006;158:450-51.

[16] Ohishi K, Zenitani R, Bando T, Goto Y, Uchida K, Maruyama T, Yamamoto T, MiyazakiI N, Fujise Y. Pathological and serological evidence of Brucella infection in baleen whales (Mysticeti) inthe western North Pacific Comp Immunol Microbiol Infect Dis. 2003;26:125-36.

[17] Ohishi K, Fujise Y, Maruyama T. Brucella spp. In the western North Pacific and Antarctic cetaceans: a review. J Cetacean Res Manag. 2008;10:67-72.

[18] Cvetnić Ž, Duvnjak S, Đuras M, Gomerčić T, Reil I, Zdelar-Tuk M, Špičić S. Evidence of Brucella strain ST27 in bottlenose dolphin (Tursiops truncatus) in Europe. Vet Microbiol. 2016;196:93-7.

[19] Alba PG, Terracciano A, Franco S, Lorenzetti C, Cocumelli G, Fichi C, Eleni M, ZygmuntYS, Cloeckaert A, Battisti A. The presence of Brucella ceti ST 26 in a striped dolphin (Stenella coeruleoalba) with meningoencephalitis from the Mediterranean Sea. Vet Microbiol. 2013;64:158-63.

[20] Dagleish MP, Barley J, Finlayson J, Reid RJ, Forster G. Brucella ceti associated pathology inthe testicle of harbour porpoise (Phocoena phocoena). J Comp Pathol. 2008;139:54-9.

[21] Dawson, CE, Stubberfield EJ, Perrett LL, King AC, Whatmore AM, Basiruddin JB, Stack JA, Macmillan AP. Phenotypic and molecular characterisation of Brucella isolates from marine mammals. BMC Microbiol. 2008;8:224-7.

[22] Guzman-Verri C, Gonzales -Barrientos R, Hernandez-Mora G, Morales JA, Baquero-Calvo E, Chavez-Olarte E, Moreno E. Brucella ceti and brucellosis in cetaceans. Front. cell. Infect. Microbiol. 2012: doi.10.3389/fcim.2012.00003.

[23] Maratea J, Ewalt DR, Frasca SJ, Dunn JL, De Guise S, Szkudlarek L, Staubin DJ, French RA. Evidence of Brucella sp. infection in marine mammals stranded along the coast of southern New England. J Zoo Wildl Med. 2003;34:256-61. 
[24] Van Bressem MF, Warebeek K, Raga JA, Godfroid J, Brew SD, MacMillan AP. Serological evidence of Brucella species infection in odontocetes from the South Pacific and the Mediterranean. Vet Rec. 2001;148:657-61.

[25] Davison NJ, Barnet JE, Perett LL, Dawson CE, PerkinsE MW, Deaville RC, Jepson PD. Meningoencephalitis and arthritis associated with Brucella ceti in a short-beaked common dolphin (Delphinus delphis). J Wild Dis. 2013;49:632-36.

[26] Jauniaux TP, Brenez C, Fretin DJ. Godfroid J, Jacques T, Kerckhof F, Mast J, Sarlet M, Coignoul L. Brucella ceti infection in harbour porpoise (Phocoena phocoena). Emerg Infect Dis. 2010;16:1966-8.

[27] Nymo IH, Tryland M, Godfroid J. A review of Brucella infection in marine mammals, with special emphasis on Brucella pinnipedialis in the hooded seal (Cystophora cristata). Vet Res. 2011;42:93-116.

[28] Tryland M, Sorensen KK, Godfroid J. Prevalence of Brucella pinnipediae in healthy hooded seals (Cystophora cristata) from the North Atlantic Ocean and ringed seals (Phoca hispida) from Svalbard. Vet Microbiol. 2005;105:103-11.

[29] Jepson PD, Brew S, Macmillan AP, Baker JR, Barnett J, Kirkwood JK, Kuiken T, Robinson IR, Simpson VR. Antibodies to Brucella in marine mammals around the coast of England and Wales. Vet Rec. 1997;5:513-5.

[30] Tryland M, Kleivane L, Alfredson A, Kjeld M, Arnason A, Stuen S, Godfroid J. Evidence of Brucella infection in marine mammals in the North Atlantic Ocean. Vet Rec. 1999;144:588-92.

[31] Tryland M, Derocher AE, Wiig Y, Godfroid J. Brucella sp. antibodies in polar bears from Svalbart and Barents Sea. J Wildl Dis. 2001;37:523-31.

[32] O'Hara TM, Holcomb D, Elzer P, Estepp J, Perry Q, Hagius S, Kirk C. Brucella species survey in polar bears (Ursus maritimus) of northern Alaska. J Wildl Dis. 2010;46:687-94.

[33] Garofolo G, Zilli K, Troiano P, Petrella A, Marrotta F, Di Serafino G, Ancora M, DI Giannatale E. Brucella ceti from two striped dolphins stranded on the Apulia coastline, Italy. J Med Microbiol. 2014;63:325-9.

[34] Isidoro-Ayza M, Ruiz-Villalobos N, Perez L, Guzman-Verri C, Munoz PM, Alegre F, Barberan M, Chacon-Diaz C, Chavez-Olarte E, Gonzales-Barrientos R, Moreno E, Blasco JM, Domingo M. Brucella ceti infection in dolphins from the Western Mediterranean Sea. BMC Vet Rec. 2014;10:206.

[35] Bricker BJ, Ewalt DR, MacMillan AP, Foster G, Brew S. Molecular characterization of Brucella strains isolated from marine mammals. J Clin Microbiol. 2000;38:1258-62.

[36] Serpe L, Gallo P, Fidanza N, Scaramuzzo, A, Fenizia, D. Single-step method for rapid detection of Brucella spp. in soft cheese by gene-specific polymerase chain reaction. J Dairy Res. 1999;66:313-7.

[37] López-Goñi I, García-Yoldi D,Marín CM, De Miguel MJ, Munoz PM, Blasco JM, Jacques I, Grayon M, Cloeckaert A, Ferreira AC, Cardoso R, Corre de Sa MI, Walravens K, Albert D, Garin-Bastuji B. Evaluation of a multiplex PCR assay (Bruce-ladder) for molecular typing of all Brucella species, including the vaccine strains. J Clin Microbiol. 2008;46:3484-7. 
[38] López-Goñi I, García-Yoldi D, Marín CM, De Miguel MJ, Barquero-Calvo E, GuzmanVerri C, Albert D, Garin-Bastuji B. New Bruce-ladder multiplex PCR assay for the biovar typing of Brucella suis and the discrimination of Brucella suis and Brucella canis. Vet Microbiol. 2011;154:152-5.

[39] Kang SI, Her M, Kim JW. Advanced multiplex PCR assay for differentiation of Brucella species. Appl Environ Microbiol. 2011;77:6726-8.

[40] Al Dahouk S, Flèche PL, Nöckler K, Jaques I, Grayon M, Scholz HC, Tomaso H, Vergnaud G, Neubauer H. Evaluation of Brucella MLVA typing for human brucellosis. J Microbiol Methods. 2007;69:137-45.

[41] Le Flèche P, Jacques I, Grayon M, Al Dahouk S, Bouchon P, Denoeud F, Nockler K, Neubauer H, Guilloteau LA, Vergnaud G. Evaluation and selection of tandem repeat loci for a Brucella MLVA typing assay. BMC Microbiol. 2006;6:9.

[42] Whatmore AM, Perrett LL, MacMillan AP. Characterisation of the genetic diversity of Brucella by multilocus sequencing. BMC Microbiol. 2007;7:34.

[43] Maio E, Begeman L, Bisselink Y, Van Tulden P, Wiersma L, Hiemstra S, Ruuls R, Grone A, Roest HI, Willemsen P, Van Der Giessen J. Identification and typing of Brucella spp. in stranded harbour porpoises (Phocoena phocoena) on the Dutch coast. Vet Microbiol. 2014;173:118-24. 


\section{Sažetak}

\section{Bruceloza u morskih sisavaca s posebnim osvrtom na Republiku Hrvatsku}

Nakon gotovo dva desetljeća istraživanja i dokaza bruceloze u morskih sisavaca, opće je poznato da je bruceloza u morskih sisavaca globalno rasprostranjena. Pozitivne životinje pronađene su u sjevernom Atlantiku, Sredozemnom moru i na Arktiku, uključujući i Barentsovo more. Zaražene ili zarazi izložene životinje otkrivene su duž atlanske i pacifičke obale Sjeverne Amerike, obale Perua, Australije, Novog Zelanda, Havaja i na Solomonskim otocima te Antarktici. Bruceloza se najčešće javlja u obalnih dupina (Phocoena phocoena), zatim u plavobijelog dupina (Stenella coeruleoalba), atlanskog bjelobokog dupina (Lagenorhynchus acutus), dobrog dupina (Tursiops truncatus) i običnog dupina (Delphinus delphis) te patuljastog kita (Balaenoptera acutostrata). Pozitivne serološke reakcije utvrđene su u 35 vrsta kitova i u 14 vrsta perajara, dvije podvrste morskih vidri, jedne vrste slatkovodnih vidri i polarnog medvjeda. Do sada je na području Sredozemnog mora bruceloza u morskih sisavaca dokazana u Italiji, Španjolskoj. Prva istraživanja bruceloze u dupina u Republici Hrvatskoj započela su u ljeto 2015. godine. Brucella sp. izdvojena je iz limfnih čvorova dobrog dupina koji je uginut nađen na području Poreča. To je prvi dokaz bruceloze dupina u Jadranskom moru. Izdvojen je i identificirana Brucella ceti soj ST27 koji je prvi puta dokazan u Europi, što može predstavljati značajnu prijetnju zdravlju ljudi.

Ključne riječi: morski sisavc; dupin; bruceloza; Brucella ceti ST 27; Hrvatska.

Corresponding author:

Željko Cvetnić

e-mail:cvetnic@veinst.hr 